\title{
Use of Black Soldier Fly Larvae for Food Waste Treatment and Energy Production in Asian Countries: A Review
}

\author{
Chul-Hwan Kim ${ }^{1}$, JunHee Ryu ${ }^{2}{ }^{(D}$, Jongkeun Lee ${ }^{2}{ }^{\infty}$, Kwanyoung Ko ${ }^{1}$, Ji-yeon Lee ${ }^{1}$, Ki Young Park ${ }^{2}$ \\ and Haegeun Chung ${ }^{1, *}$ \\ 1 Department of Environmental Engineering, Konkuk University, Seoul 05029, Korea; \\ allsidakr@korea.ac.kr (C.-H.K.); kwanyko@konkuk.ac.kr (K.K.); jyjtv1226@gmail.com (J.-y.L.) \\ 2 Department of Civil \& Environmental Engineering, Konkuk University, Seoul 05029, Korea; \\ carrot.jh@gmail.com (J.R.); leejk84@konkuk.ac.kr (J.L.); kypark@konkuk.ac.kr (K.Y.P.) \\ * Correspondence: hchung@konkuk.ac.kr; Tel./Fax:+82-2-450-0421
}

Citation: Kim, C.-H.; Ryu, J.; Lee, J.; Ko, K.; Lee, J.-y.; Park, K.Y.; Chung, H. Use of Black Soldier Fly Larvae for Food Waste Treatment and Energy Production in Asian Countries: A

Review. Processes 2021, 9, 161.

https://doi.org/10.3390/ pr9010161

Received: 24 December 2020

Accepted: 12 January 2021

Published: 15 January 2021

Publisher's Note: MDPI stays neutral with regard to jurisdictional claims in published maps and institutional affiliations.

Copyright: (c) 2021 by the authors. Licensee MDPI, Basel, Switzerland. This article is an open access article distributed under the terms and conditions of the Creative Commons Attribution (CC BY) license (https:/ / creativecommons.org/licenses/by/ $4.0 /)$.

\begin{abstract}
Food waste accounts for a substantial portion of the organic waste generated at an increasing rate worldwide. Organic waste, including food waste, is largely subjected to landfill disposal, incineration, and anaerobic digestion; however, more sustainable methods are needed for treating it. Treatment of organic waste using black soldier fly (Hermetia illucens) larvae is an environmentally safe and cost-efficient method that has been attracting increasing attention worldwide. Black soldier fly decomposes various types of organic waste and converts them into high-value biomasses such as oils and proteins. This review introduces the trends in research related to the treatment of organic waste by black soldier fly (Hermetia illucens) larvae (BSFL) and their bioconversion efficiencies in Asian countries. Perspectives on the growth of BSFL during waste treatment operation and optimal rearing conditions are provided. The trends in studies related to the application of BSFL as biofuel and animal feed are also discussed. Such use of BSFL would be beneficial in Asia, especially in countries where the technology for processing organic waste is not readily available. This review may provide further directions of investigations including culture techniques for industrial scale applications of BSFL in food waste treatment and resource production in Asian countries.
\end{abstract}

Keywords: Hermetia illucens; biofuel; animal feed; bioconversion; waste valorization

\section{Introduction}

\subsection{Trends in Food Waste Generation}

The amount of consumed food is increasing exponentially owing to the improvement in living standards and the growth of the human population. Accordingly, the quantity of food waste is increasing steadily and causing a wide range of social problems. The Food and Agriculture Organization (FAO) defined food waste as food that is discarded, generally at retail and consumption stages [1]. In Korea, food waste is defined as the waste generated or dumped during the production, distribution, processing, cooking, storage, and consumption of food and food ingredients.

More than 2.1 billion tons of municipal solid waste is generated worldwide each year, but only about $16 \%$ is recycled and more than $46 \%$ is discarded [2]. Food waste accounts for approximately 25 to $45 \%$ of municipal solid waste, which also consists of plastic, metal, glass, textile, wood, rubber, leather, and paper waste (Figure 1) [3,4]. The increase in food waste leads to an imbalance in food systems around the world, and in the case of toxic waste, it can adversely affect human health, biodiversity, and ecosystems [2].

The amount of food waste is expected to increase over the next 25 years, mainly owing to the growing economies and populations of Asian countries. For example, the amount of food waste in Asian countries could increase from 278 million to 416 million tons between 2005 and 2025 [5]. The typical food waste that is disposed of in the AsiaPacific region and around the world is summarized in Figure 1. As a country's income 
level increases, the proportion of organic waste in solid waste decreases; in low-income countries the percentage of organic waste is $64 \%$, but this value is reduced to $28 \%$ in high-income countries [6]. Thus, effective treatment technologies are required to reduce the environmental and economic burdens of organic waste.

\section{(a)}
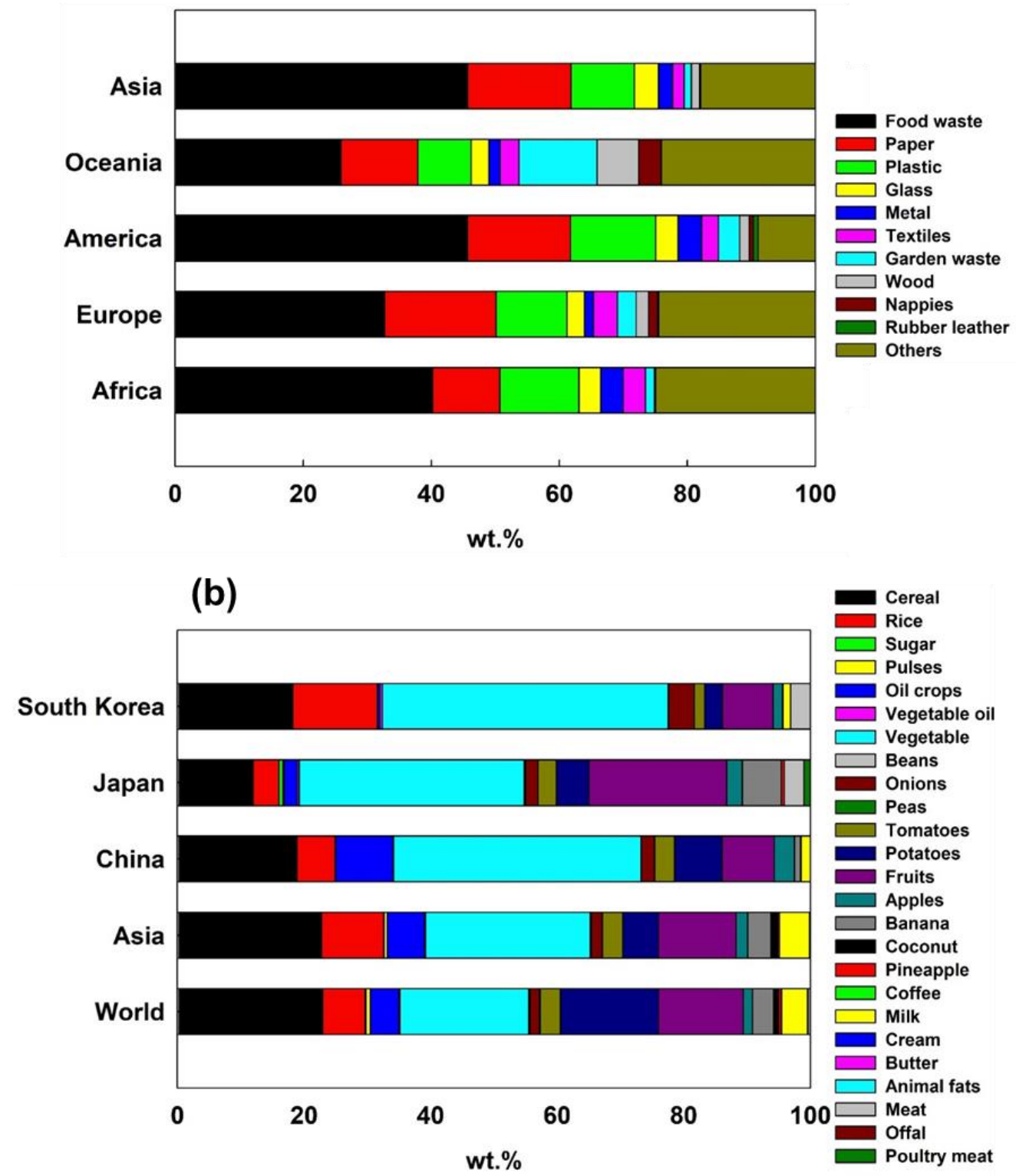

Figure 1. (a) Composition of municipal solid waste in wt.\% (modified from [4]). (b) Typical food waste in the Asia-Pacific region and worldwide in wt.\% (modified from [7]).

\subsection{Insect-Based Food Waste Treatment Methods}

Insect-based treatment of food waste is being increasingly recognized as an environmentally friendly method for recycling resources, and it also has the advantage of low installation costs. Additionally, such insects can be an excellent protein source through a certain procedure of extraction $[8,9]$. However, it is very important to maintain suitable conditions, such as feed components, adequate temperature, humidity, and acidity for the insects to survive and thrive [10]. Among the insects, food waste treatment using black soldier fly (Hermetia illucens) larvae (BSFL) is gaining significant attention [11]. BSF belongs 
to the family Diptera of the order Stratiomyidae and inhabits tropical and temperate regions worldwide [12]. The larvae breakdown various organic wastes using their strong mouth parts and powerful digestive enzymes $[13,14]$ and effectively decompose organic wastes such as the debris of rotten animals and plants [12]. Under ideal conditions of food supply, temperature, and humidity, BSFL can pupate within 2 weeks. The benefits of BSFL composting are that it treats organic waste rapidly and reduces bacterial growth and odor [14]. In addition, BSFL compete with the housefly (Musca domestica), a major mediator of disease, and may thus suppress it [15]. The BSFL also contain natural antibiotics such as defensin-like peptide 4 (DLP4), where defensin is an antibacterial peptide secreted by fungi [16], can potentially modify harmful microorganisms in manure and food waste as well as reduce the abundance of Escherichia coli 0157:H7 and Salmonella enterica [17].

The larvae and prepupae of BSF is a useful animal feed source because it is composed of protein and fat as high as $40 \%$ and $30 \%$, respectively [18,19]. Additionally, it is not harmful to humans; for example, it does not feed on grain, invade human habitats, or carry pests and diseases [20]. Because many types of organic wastes can be substrates for BSFL, BSFL-mediated waste treatment is easy to operate, and does not require a large area. Overall, there are many advantages to using the BSFL for waste treatment in terms of the environment, economy, and industrial use [12].

\section{Treatment of Organic Waste Including Food Waste Using BSFL}

Various substrates can be treated using BSFL. Livestock excreta do not decompose quickly and effectively and pollute the environment if left untreated [20]. Earlier methods for treating livestock manure mainly included high temperature composting; however, manure composting using BSFL began to garner attention starting in the early 1970s. Feces treatment using BSFL was suggested as a strategy to improve hygiene in developing countries as BSFL effectively decompose the feces while absorbing it into biomass [21]. When the feces of chicken, pig, and cow were investigated as suitable substrates for BSFL [22], the survival rate of the larvae was $80 \%$ or more in all feces and the nitrogen and phosphorus contents were reduced in all feces. Other studies also reported that BSFL reduce nutrient levels in cow manure, specifically $30-50 \%$ of nitrogen and $61-70 \%$ of phosphorus [23]. In addition, the activity of E. coli and number of Salmonella species in chicken manure was reduced when comparing feces with and without BSFL treatment [15]. Fruits and vegetables are also good substrates for BSFL [24]. Effects of fruits, vegetables, and their mixtures on larval productivity and body composition have been studied, and larval survival rate, pupa weight, and adult emergence rate were the highest in BSFL fed with the fruit and vegetable mix. The protein content was also higher in BSFL fed on the fruit and vegetable mix when compared to that of BSFL fed on fruit or vegetable alone [24].

\subsection{Factors Affecting BSFL Growth and Food Waste Treatment Efficiency}

The wide regional distribution of BSFL suggests that they can resist a wide range of environmental conditions; however, optimal conditions do exist for cultivating BSFL as shown in Figure 2. Many Asian countries have appropriate natural conditions for rearing BSF. The optimal temperature and relative humidity for rearing BSF are $26-27{ }^{\circ} \mathrm{C}$ and $60-70 \%$, respectively [25]. The optimal moisture content of substrates is $52-70 \%$, similar to the relative humidity [25] and the optimal light intensity is $135-200 \mu \mathrm{mol} / \mathrm{m}^{2}$ [26], which is highly dependent on seasonal changes and on the weather. Considering that many Asian countries, including those in southeast Asia, have high temperatures and humidity, industries related to BSF cultivation have high potential if implemented in such areas. Larval density should also be considered when decomposing food waste using BSFL. Competition between larvae changes the behavior of the colony and adversely affects the larval survival rate [14]. Therefore, when larvae are cultivated, the larval density should be controlled according to substrate conditions. It was reported that the most effective ratio of the number of larvae to gram of substrate for cultivating BSFL is 2:1 [14] (Figure 2). 
During the treatment of organic wastes, the growth of BSFL can be monitored by analyzing aspects of larval development. Larval development time, final larval weight, growth rate, and larval survival rate is reported to be $15-36.7$ days, $154-271 \mathrm{mg}, 2.3-37 \mathrm{mg} / \mathrm{d}$, and $85.6-97.1 \%$, respectively $[14,23,27-29]$. The growth of BSFL can vary depending on the types of substrates and rearing conditions. For example, the survival rate of BSFL were $87 \%, 90 \%$, and $93 \%$ when fed with food waste, fruits \& vegetables, and poultry feed, respectively. However, when fed with digested sludge, the survival rate was as low as $39 \%$ [11].

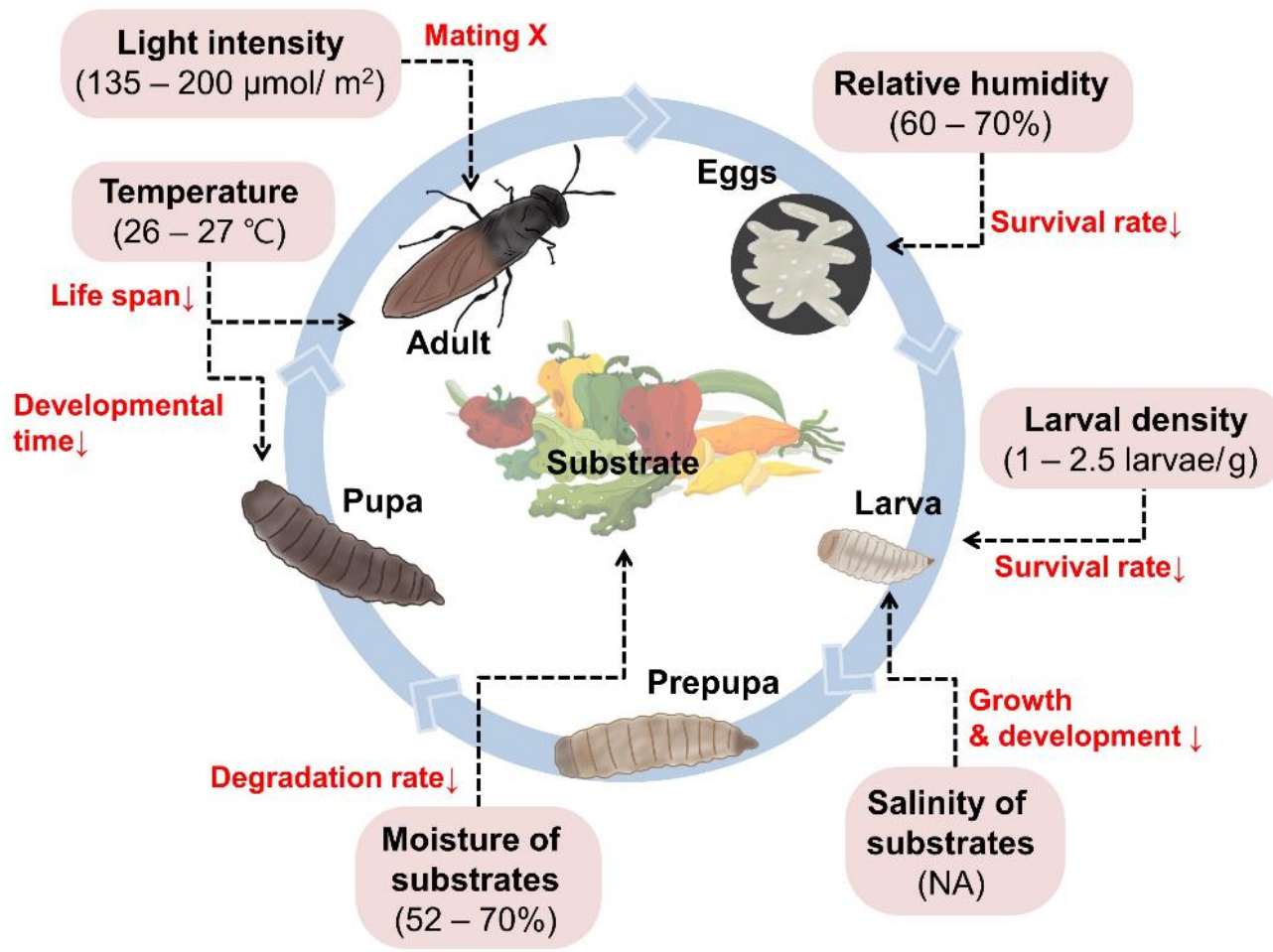

Figure 2. Factors that directly affect black soldier fly (Hermetia illucens) larvae (BSFL) growth. Optimal ranges are indicated below the factors. The consequences that follow when each factor is not properly controlled are shown in red. (i) Relative humidity: survival rate decreases when relative humidity is lower than the optimal range [25,30]; (ii) larval density: indicates the ratio between substrate weight ( $\mathrm{g}$ ) and number of larvae, and survival rate decreases when larval density is higher than the optimal range [14]; (iii) light intensity: mating does not occur depending on the light source [25,31]; (iv) temperature: adult life span and pupal development time decrease when temperature is higher than the optimal range [25,26]; (v) salinity of substrate: growth rate and development of larvae decrease when salinity of substrate increases [14]; (vi) moisture of substrates: degradation rate decreases when moisture is higher than the optimal range [25,32].

\subsection{Feed Characteristics}

Feeding is a decisive factor affecting the development of BSFL, and nutrition during the larval period is known to influence adult development. Food quality affects the larval size, survival rate, adult size, and fertility of BSF [33,34]. For this reason, the pretreatment of the substrate is key for BSFL cultivation. For instance, food processing, such as heat treatment and crushing, changes the structure of the substrate so that BSFL improve their digestion of the food waste [14]. The growth of BSF is also greatly influenced by the moisture content of the substrate [35], and excessive moisture decreases the degradation rate of the substrate [32].

A few studies have been carried out to investigate the effects of the salt concentration of the substrate on BSFL. The growth rate and development of the larvae and decomposition rate of the substrate were lower when food waste containing $\mathrm{NaCl}$ was fed to BSFL than when the food waste not containing $\mathrm{NaCl}$ was fed. This was because $\mathrm{NaCl}$ inhibited larval 
growth [13], as reported by a study in which $3 \% \mathrm{NaCl}$ in the substrate inhibited the growth of BSFL [36] (Figure 2).

\subsection{Environmental Conditions}

BSF is a eurythermal insect that can adapt to various temperatures $\left(15-47^{\circ} \mathrm{C}\right)$, despite being sensitive to temperature [37]. Temperature and humidity have a large influence on the development, mating, and spawning of BSF [38]. The larval development, adult emergence, and survival rates of BSFL reared on brewer's spent grain and cow dung were investigated, and the optimum temperature range was $25-30{ }^{\circ} \mathrm{C}$. At temperatures higher than $30^{\circ} \mathrm{C}$, the lifespan of the adults decreased. Studies have also reported that if the temperature and humidity are not properly controlled, they may seriously affect the hatching of eggs and development of BSFL [30,37]. Specifically, it was reported that BSFL grown at $27^{\circ} \mathrm{C}$ showed a slower development rate than BSFL grown at $30^{\circ} \mathrm{C}$. Additionally, when the humidity was low, the egg membrane dehydrated, and the survival rate of the egg decreased. The effect of humidity on the egg hatching and adult emergence of BSF was investigated at $25,40,50,60$, and $70 \%$ relative humidity, and the higher the relative humidity, the higher the hatching rate and emergence of the adults and the slower the development time [30] (Figure 2).

Light is needed for BSF to mate. As BSF cannot mate in winter owing to the weak intensity of light, artificial light is required [37]. Fluorescent lamps, halogen lamps, lightemitting diode (LED) lamps, and oxo bulbs can be used as sources of artificial light, but when rare earth lamps were used, mating did not occur [31].

\section{Food Waste Treatment Using BSFL in Asian Countries}

Various studies have been conducted in Asian countries regarding the use of BSF in food waste treatment and the industries including biodiesel production (Table 1). Owing to its ease of operation and cost-effectiveness, BSFL-mediated waste treatment can be beneficial in Asian countries where treatment technology and capital are insufficient. In this section, we summarize the major results of studies that have been conducted on the use of BSFL in Asian countries. This review focuses mainly on studies implemented in Asian countries including China, Korea, Malaysia, Indonesia, Vietnam, Taiwan, and Japan. Each country was selected according to the scale of food waste production, population, and number of studies on BSFL.

\subsection{China}

China is a country inhabited by more than 1.4 billion people, with an annual sewage production of 40 million tons [39]. Many studies have been conducted in China on the disposal of food waste using BSFL. The conversion rates of carbon and nitrogen and GHG emissions during food waste disposal using BSFL were investigated [40], and it was shown that the $\mathrm{pH}$ of food waste was a decisive factor influencing treatment. Specifically, the $\mathrm{pH}$ of food waste showed a negative correlation with the amount of $\mathrm{CO}_{2}$ generated but a positive correlation with $\mathrm{NH}_{3}$. These results were attributed to most $\mathrm{CO}_{2}$ being transformed into carbonate under high $\mathrm{pH}$. In the case of $\mathrm{NH}_{3}$, high $\mathrm{pH}$ accelerates the degradation of organic nitrogen and $\mathrm{NH}_{4}{ }^{+}$into $\mathrm{NH}_{3}$. Additionally, it was reported that food waste treatment using BSFL emitted lower concentrations of GHG (e.g., $\mathrm{CH}_{4}$ and $\mathrm{N}_{2} \mathrm{O}$ ) than open composting and the higher the $\mathrm{pH}$ of food waste, the more pronounced the results [40]. It was reported that the amount of $\mathrm{CH}_{4}$ and $\mathrm{N}_{2} \mathrm{O}$ emitted from waste treatment process using BSFL were $2.4 \pm 0.4 \mathrm{mg} / \mathrm{kg}$ and $1.0 \pm 0.4 \mathrm{mg} / \mathrm{kg}$, respectively, while during composting $1,500 \mathrm{mg} / \mathrm{kg}$ and $1,200 \mathrm{mg} / \mathrm{kg}$ of $\mathrm{CH}_{4}$ and $\mathrm{N}_{2} \mathrm{O}$, respectively, were emitted. Compared to open composting, BSFL-mediated waste treatment reduces anaerobes, such as methanogens and denitrifiers, owing to the air circulation provided by BSFL, preventing the generation of $\mathrm{CH}_{4}$ and $\mathrm{N}_{2} \mathrm{O}$ [40]. In addition, the gut microbial communities of BSFL hardly produce $\mathrm{CH}_{4}$ and $\mathrm{N}_{2} \mathrm{O}$ [41]. 
Table 1. Subjects of studies on BSFL in Asian countries.

\begin{tabular}{|c|c|c|c|}
\hline Countries & & Subjects & Ref. \\
\hline \multirow[t]{3}{*}{ China } & (1) & $\begin{array}{l}\text { Waste treatment } \\
-\quad \text { conversion rates of carbon and nitrogen } \\
\text { - } \quad \text { greenhouse gas emissions } \\
\text { - } \quad \text { treatment of different livestock feces } \\
\text { - } \quad \text { conversion rates of organic, volatile fatty acid (VFA), and fecal soil }\end{array}$ & {$[39,40,42]$} \\
\hline & (2) & $\begin{array}{l}\text { Biodiesel production } \\
\text { - composition analysis by gas chromatography-mass spectrometry } \\
\text { (GC-MS) }\end{array}$ & \\
\hline & (1) & $\begin{array}{l}\text { Waste treatment } \\
\text { - effects of salinity and microplastics in processed food waste on the } \\
\text { treatment efficiency of BSFL }\end{array}$ & \\
\hline \multirow[t]{2}{*}{$\begin{array}{l}\text { Republic of } \\
\text { Korea }\end{array}$} & (2) & $\begin{array}{l}\text { Metabolites secreted by BSFL } \\
-\quad \text { activity of substances extracted from the BSF } \\
-\quad \text { biochemical properties of digestive enzymes }\end{array}$ & {$[13,43-46]$} \\
\hline & (3) & $\begin{array}{l}\text { Use of BSFL as animal feed } \\
-\quad \text { defatting process }\end{array}$ & \\
\hline Malaysia & (2) & $\begin{array}{l}\text { Waste treatment } \\
\text { - } \quad \text { lipid and protein content of BSFL } \\
\text { Biodiesel production } \\
\text { - } \quad \text { composition analysis using nuclear magnetic resonance (NMR) or } \\
\text { fourier transform infrared spectroscopy (FT-IR) } \\
\text { - content of FAME extracted from plants }\end{array}$ & {$[28,47,48]$} \\
\hline Indonesia & (2) & $\begin{array}{l}\text { Waste treatment } \\
-\quad \text { fertility and survival rate of BSFL } \\
\text { Rearing techniques } \\
\text { - } \quad \text { effects of plant-based organic wastes } \\
\text { Use of BSFL as animal feed } \\
\text { - production of protein hydrolysate from BSFL }\end{array}$ & [49-51] \\
\hline Japan & (1) & $\begin{array}{l}\text { Rearing techniques } \\
\text { - } \quad \text { effect of LED light and sunlight } \\
\text { Use of BSFL as animal feed } \\
\text { - } \quad \text { comparison of BSFL with soybean meal and oil }\end{array}$ & {$[52,53]$} \\
\hline Vietnam/Taiwan & (1) & $\begin{array}{l}\text { Biodiesel production } \\
-\quad \text { purification process of BSFL oil } \\
\text { - } \quad \text { enzyme-based method for biodiesel production }\end{array}$ & {$[54,55]$} \\
\hline
\end{tabular}

In China, as the population increases, the demand for milk and meat is gradually increasing [56], leading to an increase in livestock breeding. One study evaluated the conversion rate of organic matter and VFAs as well as fecal soil performance during the composting of different livestock feces using BSFL [56]. Chicken, pig, and cow feces were inoculated with BSFL and then composted for 9 days. Composting using BSFL reduced the organic matter and nitrogen by $20.3-22.2 \%$ and $6.1-14.4 \%$, respectively, and accumulated VFAs by $25.6-80.1 \%$. Thus, composting using BSFL is an effective method in developing countries such as China as it increases feces maturity and the quality of the products obtained from composting [56]. 
In China, attempts have been made to produce biodiesel from rice straw and restaurant solid waste using BSF as well as microorganisms [42], and it was found that $43.8 \mathrm{~g}$ of biodiesel could be obtained from 2000 BSFL grown on a mixture of rice straw and restaurant solid waste. The obtained biodiesel met the standard EN 14214, published by the European Committee for Standardization, that describes the requirements and test methods regarding fatty acid methyl esters (FAME) (Table 4). The authors concluded that the conversion of lignocellulose-rich materials into biodiesel using microorganisms and BSFL is an environmentally safe waste treatment method. Biodiesel production using BSFL has also been attempted by another research group [57]. Specifically, crude fat was extracted from BSFL grown for 10 days on organic waste and converted into biodiesel, and $36 \mathrm{~g}, 58 \mathrm{~g}$, and $91 \mathrm{~g}$ of biodiesel were obtained from 1000 BSFL grown on cattle, pig, and chicken manure, respectively. These findings suggest that BSFL can replace expensive edible biomasses in biodiesel production (Table 4).

In China, where there are no strict restrictions on the use of insects as animal feed, many studies have been implemented on the use of BSFL for animal feed. In one study, the growth rate and gut health of mirror carp (Cyprinus carpio L.) fed with different concentrations of BSFL for 8 weeks were investigated [58]. No differences were found between the growth rates of mirror carp fed with or not fed with BSFL, but the gut length of the fish fed with $100 \%$ BSFL was longer than that of the fish not fed with BSFL. Thus, it was reported that BSFL feed (less than $131 \mathrm{~g} / \mathrm{kg}$ ) did not adversely affect the growth rate and gut health of the mirror carp [58]. In addition, it was confirmed that a small amount of BSFL feed lowered the lipid content of the fish and increased its antioxidant levels. Another study analyzed the body composition, blood metabolites, and tissues of the liver and intestines of sea bass (Lateolabrax japonicus) fed with BSFL and/or fishmeal for 56 days [59]. There were no differences in the growth rate, body index, liver and intestinal tissues, and antioxidant and immunity levels of the intestine between sea bass fed with BSFL or fishmeal.

\subsection{Republic of Korea}

In Korea, studies have mainly focused on the molecular biology of BSF and the antimicrobial activity of substances extracted from it. When ceropin-like peptide 1 (CLP1) was extracted from the blood lymph of BSF and purified, it showed antibacterial activity against Gram-negative bacteria [43]. In another study, peptides similar to defensin, an antibacterial peptide secreted by fungi, were isolated from BSF [44]. These defensin-like peptides (DLP3 and DLP4) showed antibacterial activity against Gram-positive bacteria. The biochemical properties of the digestive enzymes secreted by the salivary gland and intestines of black soldier fly have also been analyzed [45]. The intestinal extracts of black soldier fly showed trypsin-like protease activity, and higher activities of leucine arylamidase, $\alpha$-galactosidase, $\beta$-galactosidase, $\alpha$-mannosidase, and $\alpha$-fucosidase than those reported for the intestinal extracts of housefly. Thus, the improved BSF-mediated decomposition of organic matter such as food waste compared to other species of flies appears to be attributed to its higher amylase, lipase, and protease activities [45].

Furthermore, the defatting process required when using BSFL as feed was tested in Korea using hot water and supercritical $\mathrm{CO}_{2}$ extraction [46]. When BSFL defatting was performed using hot water, the fat content in BSFL was reduced to $16 \%$. In contrast, when the supercritical $\mathrm{CO}_{2}$ extraction method was used, the fat content in BSFL was reduced to $5 \%$ or less. Therefore, it was concluded that the supercritical $\mathrm{CO}_{2}$ extraction method may be a suitable method for the defatting of BSFL for its use as feed [46].

\subsection{Malaysia}

Among the various studies conducted on BSF in Malaysia, one study used locally produced coconut fruit as a substrate for BSFL and analyzed the lipid and protein content of the larvae grown on fermented coconut waste [28]. The growth rate was the highest in BSFL grown on coconut waste fermented for 4 weeks, and the highest lipid content was $48 \%$. In contrast, BSFL grown on unfermented coconut waste showed the lowest lipid 
content (33\%). In addition, the protein content of BSFL increased when the coconut waste was fermented for a longer duration of time. Another study attempted to increase the lipid and protein content of BSFL by feeding larvae with a mixture of coconut endosperm waste and tofu [60]. When fed with a 3:2 ratio of these components, the highest lipid content of BSFL was achieved (58\%), and the protein content was $21 \%$.

Biodiesel production using BSFL was also studied in Malaysia. Lipids were extracted from 20-day-old BSFL grown on kitchen waste and successfully converted into biodiesel, which was confirmed using Fourier-transform infrared spectroscopy (FT-IR) [47]. The potential of using BSFL for biodiesel production was also determined [48], and BSFL had a lipid content of $32 \%$ and contained $84 \%$ FAME when esterified. Therefore, it was concluded that the production of biodiesel using BSFL could be an effective strategy to mitigate the food shortages in Malaysia because the FAME content of BSFL is similar to the content of FAME extracted from plants such as coconut or palm oil.

\subsection{Indonesia}

About $60 \%$ of the total waste generated in Indonesia is organic waste [49]. Vegetables and fruits are representative organic waste products and the fertility and survival rates of BSF grown on vegetable and fruit wastes were analyzed [49]. The low survival rate of BSFL was attributed to the high moisture content of the vegetable and fruit wastes. In another study, organic matter was treated with BSFL in the Dayeuhkolot Region near Citarium River [61], and the organic matter was reduced by 56\%. The growth rate, development time, survival rate, and nutritional composition of BSFL fed with the feces of horses, sheep, and mixtures of these feces with vegetables were also analyzed [29], and it was shown that the BSFL fed with the mixture of horse feces and vegetables had the shortest development time and highest survival rate, fertility rate, and protein content. Therefore, it was suggested that to increase the growth rate and protein content of BSFL, it is necessary to add vegetables to animal feces.

Similar to the studies conducted in Malaysia, those in Indonesia attempted to cultivate BSFL using local products. In Indonesia, various types of organic waste are generated from agricultural and residential activities, and plant-based waste accounts for a large proportion of the total waste produced. The Philippine Tung tree, an evergreen tree widely cultivated for timber or medicine in Indonesia, has a relatively high oil content of 37.6$39.2 \%$ and protein content of 14.9-28.2\% [50]. The protein and oil content of BSFL fed with the Philippine Tung tree was $45 \%$ and $27 \%$, respectively, suggesting that it is a suitable substrate for BSFL. The effects of three other plant-based organic wastes produced in Indonesia, namely horse excrement, vegetable waste, and tofu dreg, on the growth of BSFL were also investigated [62], and all were reported to be suitable for cultivating BSFL.

Protein hydrolysate, which is a mixture of peptides and amino acids produced during proteolysis, exhibits various biological activities, including antioxidant and antibacterial activities, and it has numerous industrial applications. In Indonesia, an attempt was made to obtain protein hydrolysate by hydrolyzing BSF with the enzyme bromelain [51]. The protein hydrolysate produced from BSF consisted of $8.0 \%$ lysine, $7.7 \%$ leucine, and $7.2 \%$ valine, and it exhibited antioxidant activity by scavenging diphenylpicryhydrazyl (DPPH) free radicals.

\subsection{Other Asian Countries}

In Vietnam and Taiwan, several studies have been conducted on the production of biodiesel using BSFL. In Vietnam, the fatty acid composition and physicochemical properties of oil extracted from BSFL were reported [54]. The content of lauric acid, linoleic acid, and linolenic acid extracted and purified from BSFL was $28.8 \%, 11.1 \%$ and $0.4 \%$, respectively. The viscosity, the free fatty acid value, the acid value, the saponification value, the iodine value, and the peroxide index of the refined oil were $96 \pm 0.14 \mathrm{cP}$, $0.45 \pm 0.017 \%, 0.9 \pm 0.043 \mathrm{mg} \mathrm{KOH} \mathrm{g}^{-1}, 215.78 \mathrm{mg} \mathrm{KOH} \mathrm{g}^{-1}, 53.7 \mathrm{~g} \mathrm{I}_{2} / 100 \mathrm{~g}$, and $133 \mathrm{mEq} \cdot \mathrm{kg}^{-1}$, respectively. In another study, transesterification was conducted using 
solvents including methanol to produce biodiesel from BSFL [63]. Among the solvents used for transesterification, n-hexane showed 14.5 times higher biodiesel productivity compared to the process in which no solvent was used, and it was, therefore, identified as the most effective solvent for transesterification. The highest biodiesel yield of $94 \%$ was achieved when $n$-hexane and methanol were mixed at a volume ratio of 1:2. Thus, transesterification using n-hexane may be promising for lowering the costs of biodiesel production using BSFL.

In Taiwan, an enzyme-based method was proposed for the production of biodiesel from BSFL because conventional methods require a large amount of extraction solvent and a long extraction time [55]. Different proteases were used to extract biodiesel from BSFL before hexane extraction. Among the enzymes used, lipid yield was 2.2 times higher when Protame ${ }^{\circledR}$ was used than when the enzyme was not used, and this was found to be an effective pretreatment method for biodiesel production using BSFL. The extracted biodiesel met the American Society for Testing and Materials specification D6751 and European standard EN 14214. Based on these findings, it was suggested that enzymatic extraction could be an effective method for extracting lipids from BSFL.

In Taiwan, polyhydroxyalkanoate nanofibers showing antibacterial activity and cytocompatibility were produced from the pupa shells of BSF [64]. Specifically, after inoculating men's foreskin fibroblasts with those nanofibers, the cells proliferated and further inhibited the growth of the bacteria E. coli and Staphylococcus aureus. These results show the potential for the application of this nanofiber to medical materials such as bioprotective materials.

In Japan, it was investigated whether BSFL fed on food waste could replace soybean meal and oil as food for hens [52]. There was no difference in food intake and spawning rate between hens fed on BSFL and hens fed on soybean meal and oil. The study also found that the eggshells of hens fed on BSFL were thicker than those of hens fed on soybean meal and oil, and the eggs were heavier.

Another study in Japan investigated the effect of light sources in BSFL rearing. One hundred BSF adults were incubated under LED lights and sunlight [53]. More fertilized eggs were obtained from BSF adults treated with sunlight, but the spawning rate and spawning cycle were similar for both treatments. Additionally, when BSF were fed with a mixture of water and sugar, the lifespan of the adult females and males tripled and doubled, respectively, compared to that of adults fed with water only. Thus, it was concluded that feeding BSF with water and sugar under LED light conditions was an effective strategy for its incubation.

\section{Application of BSFL after Food Waste Treatment}

Throughout the process of food waste treatment using BSFL, the volume of waste is reduced as it is utilized as a substrate. When BSFL ingest substrates for their growth, the substrates are converted into nutritional compositions of BSFL. Such bioconversion process leads to the production of larval biomass, and this can be utilized for further applications in the field of waste valorization [65]. Since the production of well-grown BSFL biomass is the requisite for high-quality animal feed and biodiesel, feeding and the resulting growth of BSFL is very important $[66,67]$ (Figure 3).

The waste reduction efficiencies are strongly related to the amount of biomass production and are also related to the protein conversion. As summarized in Table 2, previous studies have analyzed the substrate reduction ratio, biomass conversion ratio, and protein conversion ratio. Generally, the substrate reduction ratio and biomass conversion ratio are shown to be approximately $50 \%$ and $13 \%$, respectively; however, the protein conversion ratio varies between studies likely due to the difference in substrate source. 


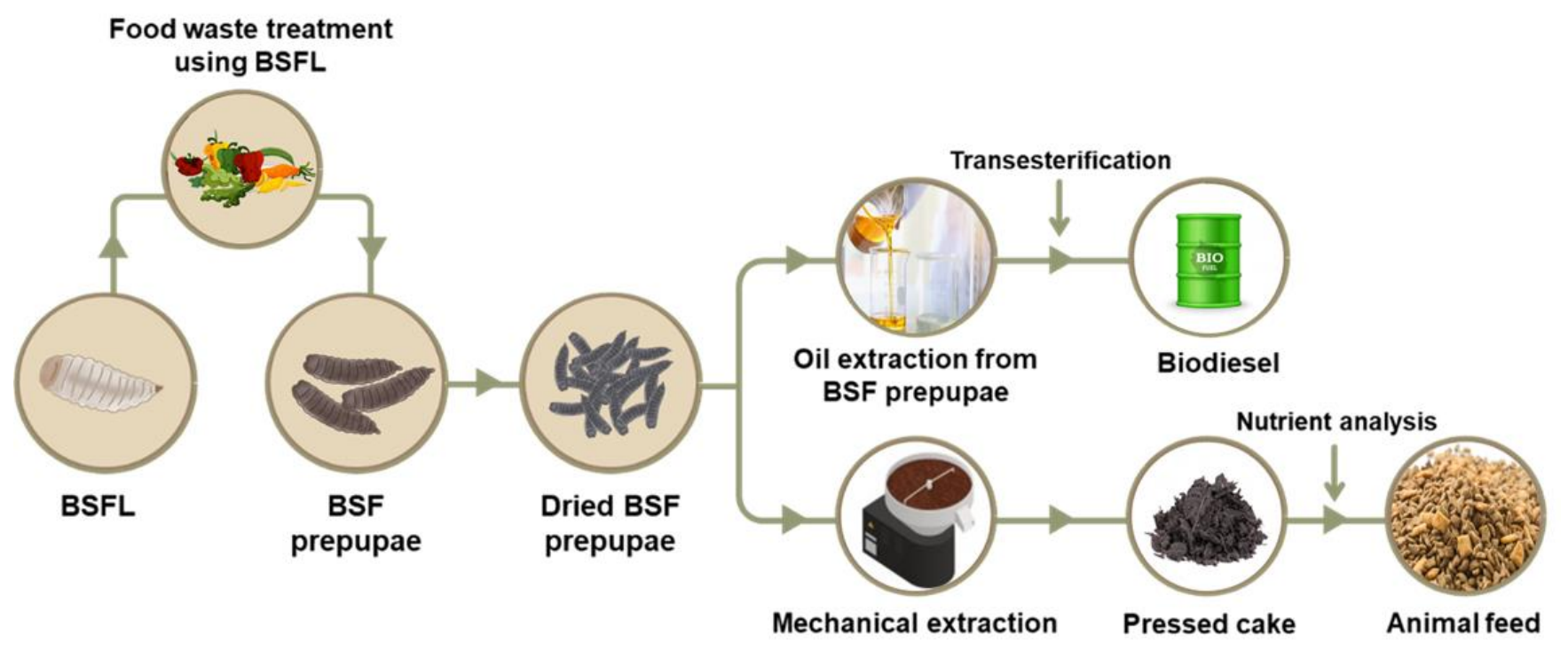

Figure 3. Process of food waste treatment using BSFL and production of biodiesel and animal feed from BSF (modified from [68]).

Table 2. Summary of treatment efficiencies of various food wastes by BSFL. Substrate reduction ratio: ratio between the amount of substrate reduced after the treatment and initial amount of substrate; biomass conversion ratio: ratio between total dry matter weight of prepupae and that of prepupae plus substrate; protein conversion ratio: ratio between total amount of protein in dry matter of prepupae and that of prepupae plus substrate. NA: Not available.

\begin{tabular}{|c|c|c|c|c|}
\hline Source & [14] & [62] & [11] & [27] \\
\hline \multirow[t]{2}{*}{ Countries } & \multicolumn{2}{|c|}{ Asian } & \multicolumn{2}{|c|}{ Non-Asian } \\
\hline & Republic of Korea & Indonesia & Sweden & New Zealand \\
\hline Waste source & School cafeteria & Vegetable & Restaurant & $\begin{array}{c}\text { Brewer's } \\
\text { waste }\end{array}$ \\
\hline Substrate reduction ratio (\%) & $50.3 \pm 1.4$ & 49.5 & $55.3 \pm 4.1$ & NA \\
\hline Biomass conversion ratio ( $\%$ ) & NA & NA & $13.9 \pm 0.3$ & $13.3 \pm 0.7$ \\
\hline Protein conversion ratio (\%) & NA & NA & $58.7 \pm 1.3$ & $10.3 \pm 0.3$ \\
\hline
\end{tabular}

\subsection{BSFL for Animal Feed}

Although the body composition of BSFL significantly differs depending on the substrate (Table 3), the high protein content of BSFL make them a good nutrition source of animal feed [46,69]. In fact, the crude protein content of BSFL after defatting was 60\% [69]. However, since the characteristics of substrates strongly affect the composition of BSFL, it is important to identify the influences of substrates to obtain BSFL biomass with suitable nutritional composition [70]. For example, one study reported that the protein content of BSFL fed with various organic wastes was between 39 to $44 \%$, while the amino acid components were more affected by the substrate type [11]. Since the protein quality can be mediated by the composition of amino acids, it is also important to consider the profiles of amino acids [71]. Another point is that the protein content shows a variation during the life cycle of BSF [72]. The protein content gradually increases up to approximately $30 \%$ until they become a prepupa and decreases after they grow into adult [72]. 
Table 3. Summary on the chemical composition of BSFL fed with food waste. NA: Not available.

\begin{tabular}{|c|c|c|c|c|c|}
\hline Source & [28] & [60] & [29] & [27] & [68] \\
\hline Countries & & Asian & & \multicolumn{2}{|c|}{ Non-Asian } \\
\hline & Malaysia & Malaysia & Indonesia & New Zealand & USA \\
\hline Waste source & Fruit & Vegetable + fruit & $\begin{array}{l}\text { Horse manure } \\
+ \text { vegetable }\end{array}$ & $\begin{array}{l}\text { Brewer's } \\
\text { waste }\end{array}$ & Cafeteria \\
\hline $\begin{array}{l}\text { Crude lipid } \\
\text { content }(\%)\end{array}$ & $42.7 \pm 2.1$ & $58.7 \pm 2.1$ & 13.0 & $33.7 \pm 0.3$ & $31.8 \pm 0.3$ \\
\hline $\begin{array}{l}\text { Crude protein } \\
\text { content }(\%)\end{array}$ & $18.6 \pm 0.2$ & $23.4 \pm 0.2$ & 46.6 & $49.9 \pm 0.2$ & $43.7 \pm 0.6$ \\
\hline Ash content ( $\%)$ & NA & NA & 14.2 & $5.7 \pm 0.1$ & $6.0 \pm 0.0$ \\
\hline
\end{tabular}

To produce animal feeds from BSFL biomass, defatting is required through separate processing, and this can lead to financial losses associated with the costs of machinery and facilities and the time required for defatting. However, partial defatting is simple enough to achieve in developing countries [73], and thus it would still be possible to use BSFL as animal feed in Asian countries (Figure 3).

The fatty acids extracted from BSFL were analyzed for their composition in previous studies conducted in Asian countries (Figure 4). In these studies, organic wastes including food waste, livestock manure, and fermented wheat bran were fed to BSFL for 7-20 days, and fatty acids were extracted from BSFL. Fatty acid analysis was mainly conducted by gas chromatography with flame ionization detector or mass spectrometry. The main fatty acids extracted from BSFL were saturated fatty acid methyl esters such as lauric acid, palmitic acid, and mysristic acid. Lauric acid was the most dominant fatty acid of BSFL, and after ingestion, this is reported to be converted into monolaurin which has antiviral, antibacterial, and antiprotozoal properties [74,75]. The weight of BSFL and lauric acid content is positively correlated, and this suggests that lauric acid is an important determinant of larval weight [74]. Moreover, the results of BSFL fatty acid analysis show that their fatty acids are useful in the food industry since their content is similar to that of palm oil and coconut fat [76].

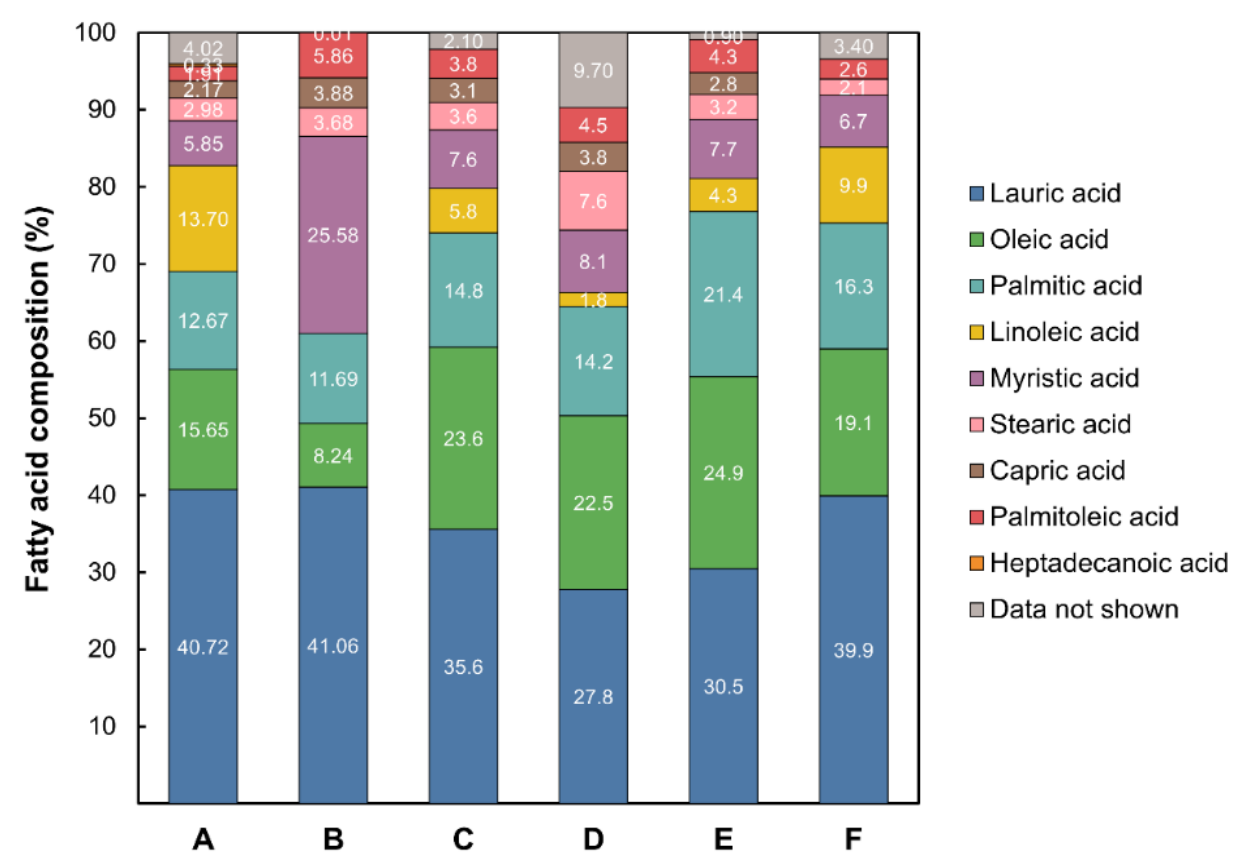

Figure 4. Comparison of composition of fatty acids extracted from BSFL in previous studies conducted in Asian countries. A: Analyzed in current study. Fatty acids were extracted from BSFL fed with processed food waste for 7 days; B: Data from [47]; C: Data from [57]; D: Data from [42]; E: Data from [63]; F: Data from [74]. 
In addition to fatty acid composition, mineral contents are also an important aspect to be considered when using BSFL as animal feed. A higher manganese, iron, zinc, copper, phosphorus, and calcium content in BSFL compared to that in other insect larvae was reported [77]. In particular, BSFL had a higher calcium content than fishmeal [77], which make them advantageous for use as feed for livestock.

Several studies have been conducted to determine the safety of BSFL used as feed [77-79]. Cadmium, lead, and zinc were shown to have no significant effects on the physiology of BSFL, but cadmium was accumulated in the body [78]. Another study reported that heavy metals had an adverse effect on development, especially cadmium and lead, which accumulated in BSFL at high concentrations. In contrast, fungal toxins and pesticides did not affect the development or accumulate in BSFL [79]. In another study, it was shown that cadmium and chromium accumulated in the larvae and prepupae [80]. Thus, monitoring heavy metals such as cadmium and lead in BSFL and in the substrate is necessary before using BSFL as feed.

\subsection{BSFL for Biodiesel Feedstock}

Biodiesel production from BSFL in Asian countries can be an excellent alternative to that using edible plant materials. The process for biodiesel production using BSFL is shown in Figure 3. After defatting the BSFL, it is possible to use the fat as biodiesel. Compared to the oil crops (e.g., palm oil or sugar cane) currently used as sources of biodiesel, BSF has a shorter life cycle, exhibits better fertility, and requires less land for production.

The quality of the lipid produced by BSFL is strongly related to the quality of biodiesel [71]. As shown in Figure 4, the main fatty acid methyl esters in BSFL such as lauric acid, palmitic acid, mysristic acid were comparable to that of conventional biodiesel $[57,63]$. Additionally, the physicochemical properties such as density, viscosity, flash point and cetane index were similar $[57,63]$, and also were consistent with the European standard EN 14,214 [42] (Table 4). According to the previous study, most insects had higher content of unsaturated fatty acid than saturated fatty acid [81]. On the other hand, BSFL-based biodiesel has higher content of saturated fatty acid than unsaturated fatty acid, and thus the oxidation stability, which is related to the storage of biodiesel and sensitivity upon exposure to the air, is comparable to conventional biodiesel [82]. Due to such oxidation stability and low viscosity, BSFL-biodiesel is considered to be high-quality biodiesel [74]. BSFL store the energy in the last cycle of their life in the form of saturated fatty acids because adult BSFL does not feed [74], and this explains their oxidation stability.

Although BSFL have a high lipid content, they are not used for food in many Asian countries and thus can be used as a substitute for sugar cane and corn in biodiesel production, thereby overcoming the ethical concerns about food shortages in developing countries. However, future research is needed on the practical use of BSFL for biodiesel production, the development of processes including extraction and purification, and the mass culture technology of BSFL.

\subsection{Economic, Environmental, and Social Aspects of BSFL-Based Resources}

Although there are many studies on life cycle assessment (LCA) in the process of bioconversion of insects, only a few studies on BSFL have been conducted [83]. However, in the context of waste valorization, applications such as biodiesel and food industry have high potential due to the advantages of BSFL mentioned earlier. Therefore, more studies about LCA evaluation on BSFL is needed. Previous studies have found that the process of bioconversion of BSFL has less environmental impact than conversion from biomass of other animal sources such as fishmeal and chicken meat $[84,85]$. The process of biodiesel production based on BSFL reduced $\mathrm{CO}_{2}$ net emission compared to conventional composting using nitrogen fertilizer [86] and lowered the global warming potential index [83]. 
Table 4. Summary of characteristics of biodiesel produced from BSFL in Asian countries. EN 14,214 indicates the requirements and test methods for fatty acid methyl esters (FAME) organized by the European committee for standardization. Yield (\%) refers to the percentage of biodiesel converted from the lipids produced by BSFL. NA: Not available.

\begin{tabular}{|c|c|c|c|c|c|}
\hline Source & $\begin{array}{c}\text { EN } \\
14214\end{array}$ & [42] & [57] & [47] & [63] \\
\hline Countries & NA & China & China & Malaysia & Taiwan \\
\hline Waste source & NA & $\begin{array}{l}\text { Restaurant solid waste } \\
\text { + rice straw }\end{array}$ & $\begin{array}{l}\text { Cattle, chicken, pig } \\
\text { manure }\end{array}$ & Restaurant & $\begin{array}{l}\text { Fermented } \\
\text { wheat bran }\end{array}$ \\
\hline Ester content $(\%)$ & $>96.5$ & 96.6 & 97.2 & NA & 98.7 \\
\hline Density at $15^{\circ} \mathrm{C}\left(\mathrm{kg} / \mathrm{m}^{3}\right)$ & $860-900$ & 895 & 885 & 875 & 875 \\
\hline $\begin{array}{c}\text { Viscosity } \\
\text { at } 40^{\circ} \mathrm{C}\left(\mathrm{mm}^{2} / \mathrm{s}\right)\end{array}$ & $3.5-5.0$ & 6.0 & 5.8 & 4.6 & 5.3 \\
\hline Water content $(\mathrm{mg} / \mathrm{kg})$ & $<500$ & 300 & NA & 387 & 300 \\
\hline Flash point $\left({ }^{\circ} \mathrm{C}\right)$ & $>120$ & 123 & 123 & 143 & 121 \\
\hline Cetane number & $>51$ & 55 & 53 & 49 & 50 \\
\hline $\begin{array}{l}\text { Acid number } \\
(\mathrm{mg} \mathrm{KOH} / \mathrm{g})\end{array}$ & $<0.5$ & 0.6 & 1.1 & NA & $<0.5$ \\
\hline Cloud point $\left({ }^{\circ} \mathrm{C}\right)$ & NA & 4.2 & NA & 5.6 & NA \\
\hline Methanol content (\%) & $<0.2$ & 0.3 & 0.3 & NA & NA \\
\hline $\begin{array}{l}\text { Distillation temperature } \\
\qquad\left({ }^{\circ} \mathrm{C}\right)\end{array}$ & NA & 360 & 360 & NA & NA \\
\hline Yield $(\%)$ & NA & NA & 96 & 97 & 94 \\
\hline
\end{tabular}

Public acceptance will be crucial to further increase the use of eco-friendly BSFL in the food industry. When comparing the flavor and meat quality of livestock fed with conventional feed and feed containing BSFL, the difference in odor, flavor, and texture was not significant [87]. Additionally, when comparing the composition of meat fed BSFL with the control group, it was confirmed that the contents of water, protein, lipids, and ash were similar [88]. Consequently, BSFL can replace soybean oil currently used for source of fat $[89,90]$. In addition, sausages containing BSFL and general sausages did not have different nutrients, and factors that determine tastes such as texture and gumminess were also not different [91].

Nevertheless, the consumption of BSFL may be poorly accepted by the public due to doubts about its safety [73]. However, most of the microorganisms that may exist in BSFL are removed during heating step such as boiling [92]. In addition, although intake patterns are different, insects such as mealworms are already used as food in Asia and Europe [93]. For the food shortage and sustainable development arising from the increasing population, the public awareness of the use of BSFL as food needs to be improved.

\section{Conclusions}

Food waste treatment using BSFL have gained great attention due to their advantages such as sustainability and possible application of BSFL-derived resources. Treatment of food waste via BSFL can contribute greatly to reducing many environmental problems such as GHG emission and the generation of harmful substances associated with existing disposal methods including landfills and incineration. In addition, BSFL can be used to produce valuable products such as oils and proteins. Through several steps of manufacturing process, high-quality biodiesel can be produced from BSFL that bioconverted food waste. Moreover, BSFL can be applied as animal feed since they have nutritional values that are comparable to existing animal feeds. Considering that the cultivation of BSFL is greatly influenced by abiotic factors such as light, temperature, and salinity, the development of culture technology is essential the economic efficiency of BSFL applications in Asian countries. Cultivating BSFL in Asian countries with adequate light and a mild climate would enable small businesses to generate high returns without high investment. As so, food waste disposal using BSFL would be a desirable method to implement in Asia where it is difficult to secure the technology required to process organic waste. Industrial 
applications of BSFL can be promoted in Asian countries through further investigations on food waste treatment and energy production, in particular culture techniques.

Author Contributions: Conceptualization, C.-H.K. and H.C.; data curation, C.-H.K., J.R., and K.K.; formal analysis, C.-H.K. and J.R.; methodology, C.-H.K. and H.C.; software, C.-H.K.; validation: C.-H.K. and J.L.; investigation, C.-H.K., J.R., J.L., K.K., J.-y.L., and H.C.; writing-original draft preparation, C.-H.K., J.R., and H.C.; writing-review \& editing, J.L., K.K., J.-y.L., K.Y.P., and H.C. All authors have read and agreed to the published version of the manuscript.

Funding: This work was supported by the Korea Environmental Industry \& Technology Institute through the Public Technology Program based on Environmental Policy Program, funded by Korea Ministry of Environment (MOE) (2018000710002).

Institutional Review Board Statement: Not applicable.

Informed Consent Statement: Not applicable.

Data Availability Statement: The data presented in this study are available in insert article.

Conflicts of Interest: The authors declare no conflict of interest.

\section{References}

1. Liu, C.; Hotta, Y.; Santo, A.; Hengesbaugh, M.; Watabe, A.; Totoki, Y.; Allen, D.; Bengtsson, M. Food waste in Japan: Trends, current practices and key challenges. J. Clean. Prod. 2016, 133, 557-564. [CrossRef]

2. Nichols, W.; Smith, N. Waste Generation and Recycling Indices 2019 Overview and Findings. Available online: https://www. circularonline,co,uk/wp-ontent/uploads/2019/07/Verisk_Maplecroft_Waste_Generation_Index_Overview_2019.pdf (accessed on 20 April 2020).

3. Brás, I.; Silva, E.; de Lemos, L.T. Feasibility of using municipal solid wastes rejected fractions as fuel in a biomass power plant. Environ. Prot. Eng. 2020, 46, 53-62. [CrossRef]

4. $\quad$ Eggleston, S.; Buendia, L.; Miwa, K.; Ngara, T.; Tanabe, K. (Eds.) 2019 Refinement to the 2006 IPCC Guidelines for National Greenhouse Gas Inventories; Institute for Global Environmental Strategies: Hayama, Japan, 2006; Volume 5.

5. Melikoglu, M.; Lin, C.; Webb, C. Analysing global food waste problem: Pinpointing the facts and estimating the energy content. Cent. Eur. J. Eng. 2013, 3, 157-164. [CrossRef]

6. Lim, S.L.; Lee, L.H.; Wu, T.Y. Sustainability of using composting and vermicomposting technologies for organic solid waste biotransformation: Recent overview, greenhouse gases emissions and economic analysis. J. Clean. Prod. 2016, 111, $262-278$. [CrossRef]

7. Kiran, E.U.; Trzcinski, A.P.; Ng, W.J.; Liu, Y. Bioconversion of food waste to energy: A review. Fuel 2014, 134, 389-399. [CrossRef]

8. Lee, H.J.; Kim, J.H.; Ji, D.S.; Lee, C.H. Effects of heating time and temperature on functional properties of proteins of yellow mealworm larvae (Tenebrio molitor L.). Food Sci. Anim. Resour. 2019, 39, 269-308. [CrossRef]

9. Choi, B.D.; Wong, N.A.K.; Auh, J.H. Defatting and sonication enhances protein extraction from edible insects. Food. Sci. Anim. Resour. 2017, 37, 955-961.

10. Yoon, C.H.; Jeon, S.H.; Ha, Y.J.; Kim, S.W.; Bang, W.Y.; Bang, K.H.; Gal, S.W.; Kim, I.S.; Cho, Y.S. Functional chemical components in Protaetia brevitarsis larvae: Impact of supplementary feeds. Food Sci. Anim. Resour. 2020, 40, 461-473. [CrossRef]

11. Lalander, C.; Diener, S.; Zurbrügg, C.; Vinnerås, B. Effects of feedstock on larval development and process efficiency in waste treatment with black soldier fly (Hermetia illucens). J. Clean. Prod. 2019, 208, 211-219. [CrossRef]

12. Singh, A.; Kumari, K. An inclusive approach for organic waste treatment and valorisation using black soldier fly larvae: A review. J. Environ. Manag. 2019, 251, 109569. [CrossRef]

13. Cho, S.; Kim, C.H.; Kim, M.J.; Chung, H. Effects of microplastics and salinity on food waste processing by black soldier fly (Hermetia illucens) larvae. J. Ecol. Environ. 2020, 44, 1-9. [CrossRef]

14. Pastor, B.; Velasquez, Y.; Gobbi, P.; Rojo, S. Conversion of organic wastes into fly larval biomass: Bottlenecks and challenges. J. Insects Food Feed 2015, 1, 179-193. [CrossRef]

15. Furman, D.P.; Young, R.D.; Catts, P.E. Hermetia illucens (Linnaeus) as a factor in the natural control of Musca domestica Linnaeus. J. Econ. Entomol. 1959, 52, 917-921. [CrossRef]

16. Li, Z.; Mao, R.; Teng, D.; Hao, Y.; Chen, H.; Wang, X.; Wang, X.; Yang, N.; Wang, J. Antibacterial and immunomodulatory activities of insect defensins-DLP2 and DLP4 against multidrug-resistant Staphylococcus aureus. Sci. Rep. 2017, 7, 1-16.

17. Erickson, M.C.; Islam, M.; Sheppard, C.; Liao, J.; Doyle, M.P. Reduction of Escherichia coli O157: H7 and Salmonella enterica serovar Enteritidis in chicken manure by larvae of the black soldier fly. J. Food Protect. 2004, 67, 685-690. [CrossRef]

18. Cummins Jr, V.C.; Rawles, S.D.; Thompson, K.R.; Velasquez, A.; Kobayashi, Y.; Hager, J.; Webster, C.D. Evaluation of black soldier fly (Hermetia illucens) larvae meal as partial or total replacement of marine fish meal in practical diets for Pacific white shrimp (Litopenaeus vannamei). Aquaculture 2017, 473, 337-344. [CrossRef] 
19. St-Hilaire, S.; Sheppard, C.; Tomberlin, J.K.; Irving, S.; Newton, L.; McGuire, M.A.; Mosley, E.E.; Hardy, R.W.; Sealey, W. Fly prepupae as a feedstuff for rainbow trout, Oncorhynchus mykiss. J. World. Aquacult. Soc. 2007, 38, 59-67. [CrossRef]

20. Liu, C.; Wang, C.; Yao, H. Comprehensive resource utilization of waste using the black soldier fly (Hermetia illucens (L.))(Diptera: Stratiomyidae). Animals 2019, 9, 349. [CrossRef]

21. Banks, I.J.; Gibson, W.T.; Cameron, M.M. Growth rates of black soldier fly larvae fed on fresh human faeces and their implication for improving sanitation. Trop. Med. Int. Health 2014, 19, 14-22. [CrossRef]

22. Oonincx, D.G.A.B.; Van Huis, A.; Van Loon, J.J.A. Nutrient utilisation by black soldier flies fed with chicken, pig, or cow manure. J. Insects Food Feed. 2015, 1, 131-139. [CrossRef]

23. Myers, H.M.; Tomberlin, J.K.; Lambert, B.D.; Kattes, D. Development of black soldier fly (Diptera: Stratiomyidae) larvae fed dairy manure. Environ. Entomol. 2014, 37, 11-15. [CrossRef]

24. Jucker, C.; Erba, D.; Leonardi, M.G.; Lupi, D.; Savoldelli, S. Assessment of vegetable and fruit substrates as potential rearing media for Hermetia illucens (Diptera: Stratiomyidae) larvae. Environ. Entomol. 2017, 46, 1415-1423. [CrossRef] [PubMed]

25. Barragan-Fonseca, K.B.; Dicke, M.; van Loon, J.J. Nutritional value of the black soldier fly (Hermetia illucens L.) and its suitability as animal feed-a review. J. Insects Food Feed. 2017, 3, 105-120. [CrossRef]

26. Shumo, M.; Khamis, F.M.; Tanga, C.M.; Fiaboe, K.K.; Subramanian, S.; Ekesi, S.; van Huis, A.; Borgemeister, C. Influence of temperature on selected life-history traits of black soldier fly (Hermetia illucens) reared on two common urban organic waste streams in Kenya. Animals 2019, 9, 79. [CrossRef] [PubMed]

27. Liu, Z.; Minor, M.; Morel, P.C.; Najar-Rodriguez, A.J. Bioconversion of three organic wastes by black soldier fly (Diptera: Stratiomyidae) larvae. Environ. Entomol. 2018, 47, 1609-1617. [CrossRef] [PubMed]

28. Mohd-Noor, S.N.; Lim, J.W.; Lam, M.K.; Uemura, Y.; Chew, T.L.; Ho, Y.C.; Mohamad, M. Lipid and protein from black soldier fly larvae fed with self-fermented coconut waste medium. J. Adv. Res. Fluid Mech. Therm. Sci. 2018, 46, 88-95.

29. Julita, U.; Suryani, Y.; Kinasih, I.; Yuliawati, A.; Cahyanto, T.; Maryeti, Y.; Permana, A.D.; Fitri, L.L. Growth performance and nutritional composition of black soldier fly, Hermetia illucens (L), (Diptera: Stratiomyidae) reared on horse and sheep manure. IOP Conf. Ser. Earth Environ. Sci. 2018, 187, 012071. [CrossRef]

30. Holmes, L.A.; Vanlaerhoven, S.L.; Tomberlin, J.K. Relative humidity effects on the life history of Hermetia illucens (Diptera: Stratiomyidae). Environ. Entomol. 2012, 41, 971-978. [CrossRef]

31. Zhang, J.; Huang, L.; He, J.; Tomberlin, J.K.; Li, J.; Lei, C.; Sun, M.; Liu, Z.; Yu, Z. An artificial light source influences mating and oviposition of black soldier flies, Hermetia illucens. J. Insect Sci. 2010, 10, 202.

32. Diener, S.; Zurbrügg, C.; Gutiérrez, F.R.; Nguyen, D.H.; Morel, A.; Koottatep, T.; Tockner, K. Black soldier fly larvae for organic waste treatment-prospects and constraints. In Proceedings of the WasteSafe 2011-2nd International Conference, Khulna, Bangladesh, 13-15 February 2011; pp. 1-8.

33. Nguyen, T.T.; Tomberlin, J.K.; Vanlaerhoven, S. Influence of resources on Hermetia illucens (Diptera: Stratiomyidae) larval development. J. Med. Entomol. 2013, 50, 898-906. [CrossRef]

34. Gobbi, P.; Martinez-Sanchez, A.; Rojo, S. The effects of larval diet on adult life-history traits of the black soldier fly, Hermetia illucens (Diptera: Stratiomyidae). Eur. J. Entomol. 2013, 110, 461. [CrossRef]

35. Cheng, J.Y.; Chiu, S.L.; Lo, I.M. Effects of moisture content of food waste on residue separation, larval growth and larval survival in black soldier fly bioconversion. Waste Manag. 2017, 67, 315-323. [CrossRef] [PubMed]

36. Kwon, J.H.; Kim, J.Y. Treatment efficiency of food waste by the black soldier fly (Hermetia illucens) depending on salinity and moisture contents. J. Korea Soc. Waste Manag. 2016, 33, 590-597. [CrossRef]

37. Park, H.H. Black Soldier Fly Larvae Manual; University of Massachusetts Amherst: Amherst, MA, USA, 2016. Available online: https://scholarworks,umass,edu/sustainableumass_studentshowcase/14/ (accessed on 15 May 2020).

38. Tomberlin, J.K.; Adler, P.H.; Myers, H.M. Development of the black soldier fly (Diptera: Stratiomyidae) in relation to temperature. Environ. Entomol. 2009, 38, 930-934. [CrossRef] [PubMed]

39. Liu, T.; Awasthi, M.K.; Awasthi, S.K.; Duan, Y.; Zhang, Z. Effects of black soldier fly larvae (Diptera: Stratiomyidae) on food waste and sewage sludge composting. J. Environ. Manag. 2020, 256, 109967. [CrossRef] [PubMed]

40. Pang, W.; Hou, D.; Chen, J.; Nowar, E.E.; Li, Z.; Hu, R.; Wang, S. Reducing greenhouse gas emissions and enhancing carbon and nitrogen conversion in food wastes by the black soldier fly. J. Environ. Manag. 2020, 260, 110066. [CrossRef]

41. Jeon, H.; Park, S.; Choi, J.; Jeong, G.; Lee, S.B.; Choi, Y.; Lee, S.J. The intestinal bacterial community in the food waste-reducing larvae of Hermetia illucens. Curr. Microbiol. 2011, 62, 1390-1399. [CrossRef]

42. Zheng, L.; Hou, Y.; Li, W.; Yang, S.; Li, Q.; Yu, Z. Biodiesel production from rice straw and restaurant waste employing black soldier fly assisted by microbes. Energy 2012, 47, 225-229. [CrossRef]

43. Park, S.I.; Yoe, S.M. A novel cecropin-like peptide from black soldier fly, Hermetia illucens: Isolation, structural and functional characterization. Entomol. Res. 2017, 47, 115-124. [CrossRef]

44. Park, S.I.; Yoe, S.M. Defensin-like peptide3 from black solder fly: Identification, characterization, and key amino acids for anti-Gram-negative bacteria. Entomol. Res. 2017, 47, 41-47. [CrossRef]

45. Kim, W.; Bae, S.; Park, K.; Lee, S.; Choi, Y.; Han, S.; Koh, Y. Biochemical characterization of digestive enzymes in the black soldier fly, Hermetia illucens (Diptera: Stratiomyidae). J. Asia-Pac. Entomol. 2011, 14, 11-14. [CrossRef]

46. Kim, S.W.; Jung, T.S.; Ha, Y.J.; Gal, S.W.; Noh, C.W.; Kim, I.S.; Lee, J.H.; Yoo, J.H. Removal of fat from crushed black soldier fly larvae by carbon dioxide supercritical extraction. J. Anim. Feed Sci. 2019, 28, 83-88. [CrossRef] 
47. Ishak, S.; Kamari, A. Biodiesel from black soldier fly larvae grown on restaurant kitchen waste. Environ. Chem. Lett. 2019, 17, 1143-1150. [CrossRef]

48. Wong, C.Y.; Lim, J.W.; Uemura, Y.; Chong, F.K.; Yeong, Y.F.; Mohamad, M.; Hermansyah, H. Insect-based lipid for biodiesel production. AIP Conf. Proc. 2018, 2016, 020150.

49. Julita, U.; Fitri, L.L.; Putra, R.E.; Permana, A.D. Survival and reproductive value of Hermetia illucens (Diptera: Stratiomyidae) on vegetable and fruits waste rearing substrate. J. Phys. Conf. Ser. 2019, 1245, 012002. [CrossRef]

50. Abduh, M.Y.; Nadia, M.H.; Manurung, R.; Putra, R.E. Factors affecting the bioconversion of Philippine tung seed by black soldier fly larvae for the production of protein and oil-rich biomass. J. Asia-Pac. Entomol. 2018, 21, 836-842. [CrossRef]

51. Firmansyah, M.; Abduh, M.Y. Production of protein hydrolysate containing antioxidant activity from Hermetia illucens. Heliyon 2019, 5, e02005. [CrossRef]

52. Kawasaki, K.; Hashimoto, Y.; Hori, A.; Kawasaki, T.; Hirayasu, H.; Iwase, S.I.; Hashizume, A.; Ido, A.; Miura, C.; Miura, T.; et al. Evaluation of black soldier fly (Hermetia illucens) larvae and pre-pupae raised on household organic waste, as potential ingredients for poultry feed. Animals 2019, 9, 98. [CrossRef]

53. Nakamura, S.; Ichiki, R.T.; Shimoda, M.; Morioka, S. Small-scale rearing of the black soldier fly, Hermetia illucens (Diptera: Stratiomyidae), in the laboratory: Low-cost and year-round rearing. Appl. Entomol. Zool. 2016, 51, 161-166. [CrossRef]

54. Mai, H.C.; Dao, N.D.; Lam, T.D.; Nguyen, B.V.; Nguyen, D.C.; Bach, L.G. Purification process, physicochemical properties, and fatty acid composition of black soldier fly (Hermetia illucens Linnaeus) larvae oil. J. Am. Oil Chem. Soc. 2019, 96, 1303-1311. [CrossRef]

55. Su, C.H.; Nguyen, H.C.; Bui, T.L.; Huang, D.L. Enzyme-assisted extraction of insect fat for biodiesel production. J. Clean. Prod. 2019, 223, 436-444. [CrossRef]

56. Liu, T.; Awasthi, M.K.; Chen, H.; Duan, Y.; Awasthi, S.K.; Zhang, Z. Performance of black soldier fly larvae (Diptera: Stratiomyidae) for manure composting and production of cleaner compost. J. Environ. Manag. 2019, 251, 109593. [CrossRef] [PubMed]

57. Li, Q.; Zheng, L.; Cai, H.; Garza, E.; Yu, Z.; Zhou, S. From organic waste to biodiesel: Black soldier fly, Hermetia illucens, makes it feasible. Fuel 2011, 90, 1545-1548. [CrossRef]

58. Xu, X.; Ji, H.; Yu, H.; Zhou, J. Influence of dietary black soldier fly (Hermetia illucens Linnaeus) pulp on growth performance, antioxidant capacity and intestinal health of juvenile mirror carp (Cyprinus carpio var. specularis). Aquacult. Nutr. 2020, 26, 432-443.

59. Wang, G.; Peng, K.; Hu, J.; Yi, C.; Chen, X.; Wu, H.; Huang, Y. Evaluation of defatted black soldier fly (Hermetia illucens L.) larvae meal as an alternative protein ingredient for juvenile Japanese seabass (Lateolabrax japonicus) diets. Aquaculture 2019, 507, 144-154. [CrossRef]

60. Mohd-Noor, S.N.; Lim, J.W.; Mah-Hussin, M.T.A.; Ramli, A.; Chew, T.L.; Bashir, M.J.K.; Tan, W.N.; Beniers, J.J.A. Potential of protein and lipid productions from black soldier fly larvae fed with mixture of waste coconut endosperm and soybean curd residue. AIP Conf. Proc. 2018, 2016, 020098.

61. Kastolani, W. Utilization of BSF to reduce organic waste in order to restoration of the citarum river ecosystem. IOP Conf. Ser. Earth Environ. Sci. 2019, 286, 012017. [CrossRef]

62. Kinasih, I.; Putra, R.E.; Permana, A.D.; Gusmara, F.F.; Nurhadi, M.Y.; Anitasari, R.A. Growth performance of black soldier fly larvae (Hermetia illucens) fed on some plant based organic wastes. HAYATI J. Biosci. 2018, 25, 79.

63. Nguyen, H.C.; Liang, S.H.; Li, S.Y.; Su, C.H.; Chien, C.C.; Chen, Y.J.; Huong, D.T.M. Direct transesterification of black soldier fly larvae (Hermetia illucens) for biodiesel production. J. Taiwan Inst. Chem. E 2018, 85, 165-169. [CrossRef]

64. Wu, C.S.; Wang, S.S. Bio-based electrospun nanofiber of polyhydroxyalkanoate modified with black soldier fly's pupa shell with antibacterial and cytocompatibility properties. ACS Appl. Mater. Inter. 2018, 10, 42127-42135. [CrossRef]

65. Manurung, R.; Supriatna, A.; Esyanthi, R.R.; Putra, R.E. Bioconversion of rice straw waste by black soldier fly larvae (Hermetia illucens L.): Optimal feed rate for biomass production. J. Entomol. Zool. Stud. 2016, 4, 1036-1041.

66. Gao, Z.; Wang, W.; Lu, X.; Zhu, F.; Liu, W.; Wang, X.; Lei, C. Bioconversion performance and life table of black soldier fly (Hermetia illucens) on fermented maize straw. J. Clean. Prod. 2019, 230, 974-980. [CrossRef]

67. Wong, C.Y.; Lim, J.W.; Chong, F.K.; Lam, M.K.; Uemura, Y.; Tan, W.N.; Bashir, M.J.K.; Lam, S.M.; Sin, J.C.; Lam, S.S. Valorization of exo-microbial fermented coconut endosperm waste by black soldier fly larvae for simultaneous biodiesel and protein productions. Environ. Res. 2020, 185, 109458. [CrossRef] [PubMed]

68. Surendra, K.C.; Olivier, R.; Tomberlin, J.K.; Jha, R.; Khanal, S.K. Bioconversion of organic wastes into biodiesel and animal feed via insect farming. Renew. Energ. 2016, 98, 197-202. [CrossRef]

69. Spranghers, T.; Ottoboni, M.; Klootwijk, C.; Ovyn, A.; Deboosere, S.; De Meulenaer, B.; Michiels. J.; Eeckhout, M.; De Clercq, P.; De Smet, S. Nutritional composition of black soldier fly (Hermetia illucens) prepupae reared on different organic waste substrates. J. Sci. Food Agr. 2017, 97, 2594-2600. [CrossRef]

70. Meneguz, M.; Schiavone, A.; Gai, F.; Dama, A.; Lussiana, C.; Renn, M.; Gasco, L. Effect of rearing substrate on growth performance, waste reduction efficiency and chemical composition of black soldier fly (Hermetia illucens) larvae. J. Sci. Food Agric. 2018, 98, 5776-5784. [CrossRef]

71. Giannetto, A.; Oliva, S.; Riolo, K.; Savastano, D.; Parrino, V.; Cappello, T.; Maisano, M.; Fasulo, S.; Mauceri, A. Waste valorization via Hermetia illucens to produce protein-rich biomass for feed: Insight into the critical nutrient taurine. Animals 2020, 10, 1710. [CrossRef] 
72. Liu, X.; Chen, X.; Wang, H.; Yang, Q.; Rehman, K.; Li, W.; Cai, M.; Li, Q.; Mazza, L.; Zhang, J.; et al. Dynamic changes of nutrient composition throughout the entire life cycle of black soldier fly. PLoS ONE 2017, 12, e0182601. [CrossRef]

73. Wang, Y.S.; Shelomi, M. Review of black soldier fly (Hermetia illucens) as animal feed and human food. Foods 2017, 6, 91. [CrossRef]

74. Ewald, N.; Vidakovic, A.; Langeland, M.; Kiessling, A.; Samples, S.; Lalander, C. Fatty acid composition of black soldier fly larvae (Hermetia illucens)_Possibilities and limitations for modification through diet. Waste Manag. 2020, 102, 40-47. [CrossRef]

75. Ushakova, N.A.; Brodskii, E.S.; Kovalenko, A.A.; Bastrakov, A.I.; Kozlova, A.A.; Pavlov, D.S. Characteristics of lipid fractions of larvae of the black soldier fly Hermetia illucens. Dokl. Biochem. Biophys. 2016, 468, 209-212. [CrossRef] [PubMed]

76. Matthäus, B.; Piofczyk, T.; Katz, H.; Pudel, F. Renewable resources from insects, exploitation, properties, and refining of fat obtained by cold-pressing from Hermetia illucens (black soldier fly) larvae. Eur. J. Lipid Sci. Technol. 2018, 121, 1800376. [CrossRef]

77. Makkar, H.P.; Tran, G.; Heuzé, V.; Ankers, P. State-of-the-art on use of insects as animal feed. Anim. Feed Sci. Tech. 2014, 197, 1-33. [CrossRef]

78. Diener, S.; Zurbrügg, C.; Tockner, K. Bioaccumulation of heavy metals in the black soldier fly, Hermetia illucens and effects on its life cycle. J. Insects Food Feed 2015, 1, 261-270. [CrossRef]

79. Purschke, B.; Scheibelberger, R.; Axmann, S.; Adler, A.; Jäger, H. Impact of substrate contamination with mycotoxins, heavy metals and pesticides on the growth performance and composition of black soldier fly larvae (Hermetia illucens) for use in the feed and food value chain. Food Addit. Contam. A 2017, 34, 1410-1420. [CrossRef] [PubMed]

80. Gao, Q.; Wang, X.; Wang, W.; Lei, C.; Zhu, F. Influences of chromium and cadmium on the development of black soldier fly larvae. Environ. Sci. Pollut. R 2017, 24, 8637-8644. [CrossRef]

81. Mariod, A.A. Insect oil and protein: Biochemistry: Food and other uses: Review. Agric. Sci. 2013, 4, 76-80.

82. Ramos, M.J.; Fernández, C.M.; Casas, A.; Rodríguez, L.; Pérez, Á. Influence of fatty acid composition of raw materials on biodiesel properties. Bioresour. Technol. 2009, 100, 261-268. [CrossRef]

83. Salomone, R.; Saija, G.; Mondello, G.; Giannetto, A.; Fasulo, S.; Savastano, D. Environmental impact of food waste bioconversion by insects: Application of Life Cycle Assessment to process using Hermetia illucens. J. Clean. Prod. 2017, 140, 890-905. [CrossRef]

84. Smetana, S.; Schmitt, E.; Mathys, A. Sustainable use of Hermetia illucens insect biomass for feed and food: Attributional and consequential life cycle assessment. Resour. Conserv. Recycl. 2019, 144, 285-296. [CrossRef]

85. Ravi, H.K.; Degrou, A.; Costil, J.; Trespeuch, C.; Chemat, F.; Vian, M.A. Larvae mediated valorization of industrial, agriculture and food wastes: Biorefinery concept through bioconversion, processes, procedures, and products. Processes 2020, 8, 857. [CrossRef]

86. Guo, H.; Jiang, C.; Zhang, Z.; Lu, W.; Wang, H. Material flow analysis and life cycle assessment of food waste bioconversion by black soldier fly larvae (Hermetia illucens L.). Sci. Total Environ. 2021, 750, 141656. [CrossRef] [PubMed]

87. Cullere, M.; Tasoniero, G.; Giaccone, V.; Acuti, G.; Marangon, A.; Dalle, Z.A. Black soldier fly as dietary protein source for broiler quails: Meat proximate composition, fatty acid and amino acid profile, oxidative status and sensory traits. Animal 2018, 12, 640-647. [CrossRef] [PubMed]

88. Cullere, M.; Schiavone, A.; Dabbou, S.; Gasco, L.; Dalle, Z.A. Meat quality and sensory traits of finisher broiler chickens fed with black soldier fly (Hermetia illucens L.) larvae fat as alternative fat source. Animals 2019, 9, 140. [CrossRef]

89. Schiavone, A.; Cullere, M.; De Marco, M.; Meneguz, M.; Biasato, I.; Bergagna, S.; Dezzutto, D.; Gai, F.; Dabbou, S.; Gasco, L.; et al. Partial or total replacement of soybean oil by black soldier fly larvae (Hermetia illucens L.) fat in broiler diets: Effect on growth performances, feed-choice, blood traits, carcass characteristics and meat quality. Ital. J. Anim. Sci. 2016, 16, 93-100. [CrossRef]

90. Sypniewski, J.; Kierończyk, B.; Benzertiha, A.; Mikołajczak, Z.; Oszmałek, E.P.; Kołodziejski, P.; Sassek, M.; Rawski, M.; Czekała, W.; Józefiak, D. Replacement of soybean oil by Hermetia illucens fat in turkey nutrition: Effect on performance, digestibility, microbial community, immune and physiological status and final product quality. Br. Poult. Sci. 2020, 61, 294-302. [CrossRef]

91. Bessa, L.W.; Pieterse, E.; Sigge, G.; Hoffman, L.C. An exploratory study into the use of black soldier fly (Hermetia illucens) larvae in the production of a Vienna-style sausage. Meat Muscle Biol. 2019, 3, 289-298. [CrossRef]

92. Klunder, H.C.; Wolkers, R.J.; Korpela, J.M.; Nout, M.J.R. Microbiological aspects of processing and storage of edible insects. Food Control 2012, 26, 628-631. [CrossRef]

93. Bessa, L.W.; Pieterse, E.; Marais, J.; Hoffman, L.C. Why for feed and not for human consumption? The black soldier fly larvae. Compr. Rev. Food Sci. Food Saf. 2020, 19, 2747-2763. [CrossRef] 